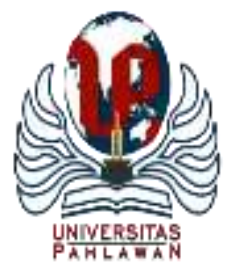

\title{
JURNALBASICEDU
}

Volume 6 Nomor 1 Tahun 2022 Halaman 869 - 876

Research \& Learning in Elementary Education

https://jbasic.org/index.php/basicedu

\section{Analisis Pemanfaatan Teknologi Informasi dalam Pembelajaran Daring pada Masa Pandemi COVID-19 di Sekolah Dasar}

\author{
Yulistina Nur DS ${ }^{1 凶}$, Harmawati ${ }^{2}$, Restaringga Maulana ${ }^{3}$
}

Pendidikan Guru Sekolah Dasar, Universitas Buana Perjuangan Karawang, Indonesia ${ }^{1,2,3}$

E-mail: yulistina.nur@ubpkarawang.ac.id1ㅗ. harmawati@ubpkarawang.ac.id² ${ }^{2}$, sd17.restaringgamaulana@mhs.ubpkarawang.ac.id ${ }^{3}$

\begin{abstract}
Abstrak
Pandemi COVID-19 ini memberikan dampak pada banyak pihak, kondisi ini sudah merambah pada dunia pendidikan. Perubahan sistem pendidikan memberikan kesulitan kepada guru serta siswa untuk menerima materi pembelajaran dikarenakan pembelajaran yang biasanya dilakukan secara tatap muka kini berubah menjadi pembelajaran jarak jauh atau dilakukan secara daring, yang pelaksanaannya tidak terlepas dari peranan teknologi informasi. Seiring dengan perkembangan zaman teknologi semakin berkembang, saat ini ada beberapa teknologi informasi yang dapat dimanfaatkan sebagai media pembelajaran seperti menggunakan e-learning, google classroom, edmodo, moodle, zoom meeting, whatsapp. Penelitian ini bertujuan untuk menganalisis pemanfaatan teknologi informasi pada masa pandemi COVID-19 di SDN Palumbonsari III. Metode yang digunakan dalam penelitian ini yaitu kualitatif deskriptif. Adapun teknik pengumpulan data dalam penelitian ini menggunkan observasi, wawancara dan dokumentasi kepada subjek penelitiannya yaitu kepala sekolah, dua orang guru kelas, dan empat orang siswa. Hasil penelitian ini menunjukkan bahwa proses pelaksanaan pembelajaran daring di SDN Palumbonsari III sudah terlaksana dengan cukup baik tetapi masih dinyatakan belum maksimal karena adanya beberapa kendala. Proses pembelajaran daring seluruhnya dilaksanakan melalui aplikasi whatsapp dan youtube. Aplikasi tersebut dianggap paling efektif untuk dilaksanakannya proses pembelajaran daring pada siswa sekolah dasar.
\end{abstract}

Kata Kunci: Teknologi informasi, Pembelajaran Daring, COVID-19

\section{Abstract}

The COVID-19 pandemic has had an impact on many parties, this condition has penetrated the world of education. Changes in the education system make it difficult for teachers and students to receive learning materials because learning that is usually done face-to-face has now turned into distance learning or is done online whose implementation cannot be separated from the role of information technology. Along with the development of the era of increasingly developing technology, currently there are several information technologies that can be used as learning media such as using e-learning, Google Classroom, Edmodo, Moodle, Zoom Meeting, WhatsApp. This study aims to analyze the utilization of information technology during the COVID-19 pandemic at SDN Palumbonsari III. The method used in this research is descriptive qualitative. Data collection techniques in this study used observation, interviews and documentation to the research subjects, namely the principal, two classroom teachers, and four students. The results of this study indicate that the process of implementing online learning at SDN Palumbonsari III has been implemented quite well but is still not optimal due to several obstacles. The online learning process is fully carried out through the WhatsApp and YouTube applications. The application is considered the most effective for the implementation of the online learning process for elementary school students

Keywords: Information Technology, COVID-19, Online Learning

Copyright (c) 2022 Yulistina Nur DS , Harmawati, Restaringga Maulana

$\triangle$ Corresponding author :

Email : yulistina.nur@ubpkarawang.ac.id

DOI : https://doi.org/10.31004/basicedu.v6i1.2022

ISSN 2580-3735 (Media Cetak)

ISSN 2580-1147 (Media Online)

Jurnal Basicedu Vol 6 No 1 Tahun 2022

p-ISSN 2580-3735 e-ISSN 2580-1147 


\section{PENDAHULUAN}

Saat ini hampir seluruh negara di dunia tidak terkecuali Indonesia sedang dilanda wabah corona virus disease 2019 (COVID-19). Supaya meminimalisir penyebaran COVID-19 pemerintah melakukan upayaupaya seperti melarang adanya kerumunan, pembatasan sosial (social distancing), menjaga jarak fisik (physical distancing), memakai masker dan mencuci tangan. Pandemi COVID-19 ini memberikan dampak pada banyak pihak, kondisi ini sudah merambah pada dunia pendidikan. Semua lembaga pendidikan khususnya sekolah dasar (SD) mulai mengubah strategi pembelajaran yang awalnya adalah tatap muka dengan mengubah menjadi pembelajaran non-tatap muka atau ada yang menyebut pembelajaran Dalam Jaringan (Daring) dan juga Pembelajaran Jarak Jauh (PJJ). Pelaksanaan pembelajaran daring tersebut memberikan tantangan tersendiri bagi guru, siswa, institusi dan bahkan memberikan tantangan bagi masyarakat luas seperti para orang tua. Dalam pelaksanaan pembelajaran daring guru harus mencari cara bagaimana agar tetap bisa menyampaikan materi pembelajaran dan dapat diterima dengan mudah oleh siswa. Menurut Putria dkk. (2020) "pembelajaran daring merupakan sebuah pembelajaran yang dilakukan dalam jarak jauh melalui media berupa internet dan lebih menekankan pada ketelitian dan mengolah informasi yang disajikan secara online".

Pelaksanaan pembelajaran daring tentunya tidak terlepas dari peranan teknologi. Teknologi dapat memberikan kemudahan dalam segala kebutuhan pada proses belajar mengajar. Menurut Adisel \& Gawdy (2020) mengemukakan bahwa teknologi informasi dapat membuat bahasan menjadi menarik, tidak monoton, mudah dipahami serta mengembangkan aktivitas pembelajaran yang jelas dan daya jangkau yang luas. Seiring dengan perkembangan zaman teknologi semakin berkembang, saat ini ada beberapa teknologi informasi yang dapat dimanfaatkan sebagai media pembelajaran salah satunya dengan menggunakan e-learning. Menurut Pakpahan \& Fitriani (2020) "e-learning merupakan model pembelajaran yang memanfaatkan fasilitas teknologi informasi dan komunikasi dan untuk mendukung proses pembelajaran jarak jauh". Teknologi infromasi lainnya yang dapat membantu pelaksanaan pembelajaran daring seperti google classroom, edmodo, moodle, zoom meeting, whatsapp. Menurut Hanifah dkk. (2020) mengemukakan bahwa "saat ini banyak platform yang dapat membantu pelaksanaan pembelajaran daring seperti e-learning, google classroom, edmodo, moodle, Rumah belajar, dan bahkan platform dalam bentuk video conference sudah semakin banyak diantaranya seperti google meet, zoom meeting, dan visco webex".

Cintiasih (2020), mengemukakan bahwa pembelajaran daring atau yang lebih sering disebut dengan $E$ learning merupakan pembelajaran berbasis teknologi informasi yang dilakukan secara online atau tidak dengan tatap muka di kelas. E-learning merupakan singkatan dari elektronik learning, merupakan suatu istilah populer dalam pembelajaran online berbasis internet dan internet. Menurut Nadziroh (2017) mengemukakan bahwa, E-learning merupakan model pembelajaran yang memanfaatkan teknologi informasi berbasis web yang dapat diakses dari jarak jauh sehingga pembelajaran yang dilaksanakan tidak hanya terpaku dalam ruang kelas dan dalam waktu tertentu saja tetapi dapat juga dilaksanakan di manapun dan kapan pun.

Teknologi informasi adalah suatu teknologi yang dapat digunakan untuk memperoleh, mengirim, mengolah, menafsirkan, menyimpan, mengorganisasikan, dan menggunakan data secara bermakna untuk memperoleh informasi berkualitas yaitu infromasi yang relavan, akurat, dan tepat waktu. Menurut Darimi (2017), teknologi informasi adalah meliputi hal yang berkaitan dengan proses, penggunaan sebagai alat bantu, manipulasi, dan pengelolaan infromasi. Pemanfaatan teknologi informasi adalah proses mamanfaatkan sutau teknologi yang digunakan untuk mengolah data untuk menghasilkan informasi yang berkualitas. Pemanfaatan teknologi informasi dan komunikasi mempunyai peran penting karena kunci keberhasilan dari pembelajaran online pada masa pandemic COVID-19 (Huda, 2020). Sejalan dengan penelitian yang dilakukan oleh (Astini, Sari, 2020), pemanfataan teknologi dalam pembelajaran daring pada tingkat sekolah dasar lebih efektif khususnya di kelas atas dengan menggunakan aplikasi google classroom dan aplikasi zoom. Sedangkan untuk kelas bawah aplikasi yang efektif digunakan adalah aplikasi whatshapp group. Kemudian penelitian yang 
dilakukan oleh (Habibah et al., 2020), menyatakan bahwa teknologi media pembelajaran yang banyak digunakan oleh sekolah dasar adalah whatsapp group (WAG) dan google classroom. Menurut Afrianti (2018), google classroom atau ruang kelas google merupakan suatu serambi pembelajaran campuran untuk ruang lingkup pendidikan yang dapat memudahkan pengajar dalam membuat, membagikan dan menggolongkan setiap penugasan tanpa kertas. Zoom meeting merupakan sebuah media pembelajaran menggunakan video. Zoom merupakan aplikasi komunikasi dengan menggunakan video. Aplikasi tersebut dapat digunakan dalam berbagai perangkat seluler, desktop, hingga telepon dan sistem ruang. Menurut Naserly (2020), zoom merupakan sebuah layanan konferensi video yang memiliki kemampuan praktis dalam menghadirkan suasana meeting secara daring. Penelitian tentang manfaat penggunaan aplikasi zoom dalam pembelajaran daring dilakukan oleh (Kuntarto et al., 2021) yaitu menyatakan bahwa aplikasi zoom memberikan banyak manfaatn bagi guru dan siswa selama pembelajaran dari di masa pandemi.

Berdasarkan hasil wawancara dan observasi awal pada guru di SDN Palumbonsari III, pembelajaran daring masih kurang efisien dan optimal khususnya pada pemanfaatan teknologi yang digunakan oleh guru. Selain itu, ada beberapa peserta didik yang belum memiliki fasilitas belajar secara daring. Sama halnya penelitian yang dilakukan terdahulu (Natsir et al., 2021), menyatakan bahwa hambatan dalam pembelajaran daring disebabkan salah satunya oleh faktor kurang mampunya guru menggunakan dan mengembangkan media pembelajaran berbasis teknologi dan informasi, hanya sebagian siswa yang mempunyai fasilitas belajar online, dan kurangnya minat peserta didik untuk menggunakan fasilitas yang disediakan oleh sekolah jika peserta didik tidak mempunyai fasilitas belajar secara daring. Selain itu kendala dalam pembelajaran daring adalah kurangnya dukungan fasilitas, akses internet yang tidak stabil, serta penyampaian materi oleh guru kurang maksimal karena hanya tatap maya (Amran et al., 2021).

SDN Palumbonsari III merupakan salah satu sekolah yang menerapkan pembelajaran daring. Berdasarkan observasi dengan guru di SDN Palumbonsari III, dalam pelaksanaan pembelajaran daring guru menggunakan teknologi informasi dan komunikasi berupa aplikasi whatsapp, youtube, zoom meeting, dan google classroom. Sehingga berdasarkan uraian di atas penelitian ini bertujuan untuk menganalisis pemanfaatan teknologi informasi dalam pembelajaran daring pada masa pandemi COVID-19 di sekolah dasar.

Berdasarkan uraian di atas, peneliti akan melakukan penelitian yang bertujuan untuk mendeskripsikan pemanfaataan teknologi informasi dan mendeskripsikan faktor yang menyebabkan kesulitan yang dialami guru dan siswa dalam pembelajaran daring di sekolah dasar. Adapun manfaat dari penelitian ini adalah memberikan masukan dan informasi untuk guru atau sekolah dalam mengevaluasi pemanfaatan teknologi informasi yang efisien untuk pelaksanaan pembelajaran secara daring.

\section{METODE PENELITIAN}

Jenis penelitian yang digunakan dalam penelitian ini adalah metode kualitatif dengan pendekatan deskriptif. Penelitian kualitatif deskriptif merupakan penelitian dengan mengumpulkan data dengan teknik wawancara, observasi, dan dokumentasi. Data maupun hasil penelitian yang telah diperoleh, dijelaskan dan dikembangkan menggunakan kata-kata peneliti yang berbentuk deskriptif. Menurut Sugiyono (2017), menyatakan bahwa metode penelitian kualitatif adalah metode penelitian yang berlandasan pada filsafat postpositivisme atau enterpretitif, digunakan untuk meneliti kondisi objek yang alamiah, dimana peneliti adalah instrumen kunci, teknik pengumpulan data dilakukan secara triangulasi (gabungan observasi, wawancara, dan dokumentasi), data yang diperoleh cenderung kualitatif, analisis data bersifat induktif/kualitatif, dan hasil penelitian bersifat untuk memahami makna, memahami keunikan, mengkonstruksi fenomena, dan menemukan hipotesis. Subjek penelitian yang digunakan dalam penelitian ini adalah penelitinya adalah kepala sekolah SDN Palumbonsari III, dua orang guru kelas SDN Palumbonsari III, dan empat orang siswa SDN Palumbonsari III. Peneiti melakukan teknik purposive sampling (sampel 
bertujuan) yang dipilih berdasarkan tujuan yang hendak dicapai yaitu mengetahui pelaksanaan pembelajaran daring dan pemanfaatan teknologi informasi dalam pembelajaran daring. Purpose sampling menurut Sugiyono (2017) teknik pengambilan sampel dengan pertimbangan tertentu.

Adapun prosedur penelitian yang akan dilaksanakan dalam penelitian ini meliputi empat tahapan, yaitu: 1) tahap persiapan; 2) tahap pelaksanaan; 3) tahap analisis data; 4) tahap penyusunan laporan. Menurut Sugiyono (2017), teknik pengumpulan data merupakan langkah paling strategis dalam penelitian karena tujuan utama dari penelitian adalah mendapatkan data. Instrumen yang digunakan dalam penelitian ini berupa pedoman observasi, wawancara, dan dokumentasi. Menurut Sugiyono (2017) menyatakan bahwa, teknik triangulasi adalah teknik pengumpulan data yang bersifat menggabungkan dari berbagai teknik yang ada dan sumber data yang ada. Peneliti menggunakan sumber data seperti dokumen, arsip, hasil wawancara, hasil observasi atau juga dengan wawancara lebih dari satu subjek yang dianggap memiliki sudut pandang yang berbeda.

Teknik analisis data yang digunakan pada penelitian ini adalah model Mails \& Huberman dalam Sugiyono, (2017) dengan tahapan pengumpulan data, yaitu: 1) pengumpulan data; 2) redukasi data; 3) penyajian data; 4) penarikan kesimpulan. Menurut Sugiyono (2017), menyatakan bahwa analisis data dalah proses mencari dan merencakan secara sistematis data yang telah diperoleh dari hasil wawancara, observasi, dam dokumentasi dengan cara menyusun bagian data ke dalam kategori, menjabarkan ke dalam bagian terkecil, melakukan sintesia, menyusun ke dalam pola, memilih mana yang penting dan yang dapat dipelajari, dan membuat kesimpulan sehingga bisa mudah untuk dipahami oleh diri sendiri maupun orang lain.

\section{HASIL DAN PEMBAHASAN}

Selama masa pandemi COVID-19 semua kegiatan belajar mengajar di SDN Palumbonsari III dilaksanakan secara daring. Berdasarkan hasil wawancara kepada subjek penelitian yaitu 2 orang guru kelas dan 2 siswa kelas IV SDN Palumbonsari III didapatkan pernyataan sebagai berikut:

Tabel 1 Hasil Wawancara Guru

\begin{tabular}{ccl}
\hline No. & Nama Subjek & \multicolumn{1}{c}{ Wawancara } \\
\hline Ibu EC (Guru kelas) & 1. & Bagaimana proses pelaksanaan pembelajaran daring di SDN \\
& Palumbonsari III? \\
& Jawaban: \\
& Pelaksanaan pembelajaran di SDN Palumbonsari III saat ini \\
& semua dilakukan secara daring. Pembelajaran daring ini cukup \\
& sulit, karena ada beberapa siswa yang orang tuanya belum \\
& memiliki handphone android, orang tua tidak bisa menggunakan \\
& handphone android, jaringan internet dan kuota pun menjadi \\
& menghambat proses pembelajaran. \\
1. & Jawaban: \\
& Pembelajaran daring di kelas IV ini sulit, karena selain ada \\
& beberapa siswa yang orang tuanya belum memiliki handphone \\
& android, jaringan internet dan kuota menjadi penghambat proses \\
& pembelajaran daring. Ibu EC pun merasa kesusahan menjelaskan \\
& materi pembelajaran, lebih mudah jika tatap muka. \\
\hline Ibu AH (Guru kelas) & \\
\hline Ibu EC (Guru kelas) & Apakah ada kesulitan yang dihadapi ibu/bapak dalam proses \\
& pembelajaran daring pada masa pandemi COVID-19? \\
& Jawaban: \\
& Ibu kesulitan untuk menjelaskan materi pembelajaran, dan \\
& kesuliatan menghubungi anak-anak yang tidak memiliki \\
\hline
\end{tabular}


DOI: https://doi.org/10.31004/basicedu.v6i1.2022

\begin{tabular}{|c|c|c|}
\hline No. & Nama Subjek & Wawancara \\
\hline \multirow{4}{*}{2.} & & handphone \\
\hline & Ibu AH (Guru kelas) & $\begin{array}{l}\text { Jawaban: } \\
\text { Kesulitan tidak semua siswa memegang handphone dan tidak } \\
\text { semua orangtua tidak memiliki handphone android, jaringan } \\
\text { internet juga tidak stabil }\end{array}$ \\
\hline & Siswa I & $\begin{array}{l}\text { Jawaban: } \\
\text { Susah memahami materi pembelajaran dan signal yang kadang } \\
\text { tidak stabil }\end{array}$ \\
\hline & Siswa II & $\begin{array}{l}\text { Jawaban: } \\
\text { Kesulitan memahami materi dan mencari jawaban }\end{array}$ \\
\hline \multirow[t]{2}{*}{3.} & Ibu EC (Guru kelas) & $\begin{array}{l}\text { 3. Bagaimana pemanfaatan teknologi } \text { informasi dalam } \\
\text { pembelajaran daring pada masa pandemi COVID-19 di SDN } \\
\text { Palumbonsari III? } \\
\text { Jawaban: } \\
\text { Ibu hanya menggunakan dua aplikasi yaitu whatsApp dan } \\
\text { youtube }\end{array}$ \\
\hline & Ibu AH (Guru kelas) & $\begin{array}{l}\text { Jawaban: } \\
\text { Sangat membantu, karena jika tidak ada whatsapp dan youtube } \\
\text { pembelajaran daring tidak bisa disampaikan }\end{array}$ \\
\hline \multirow[t]{2}{*}{4.} & Ibu EC (Guru kelas) & $\begin{array}{l}\text { 4. Apa yang menjadi kendala ibu/bapak dalam memanfaatkan } \\
\text { teknologi infromasi dalam proses pembelajaran? } \\
\text { Jawaban: } \\
\text { Ibu tidak terlalu hapam IT jadi hanya menggunakan } 2 \text { aplikasi } \\
\text { saja }\end{array}$ \\
\hline & Ibu AH (Guru kelas) & $\begin{array}{l}\text { Jawaban: } \\
\text { Tidak memiliki handphone, orang tua tidak bisa menggunakan } \\
\text { handphone android }\end{array}$ \\
\hline
\end{tabular}

Tabel 2 Hasil Wawancara Kepada Siswa

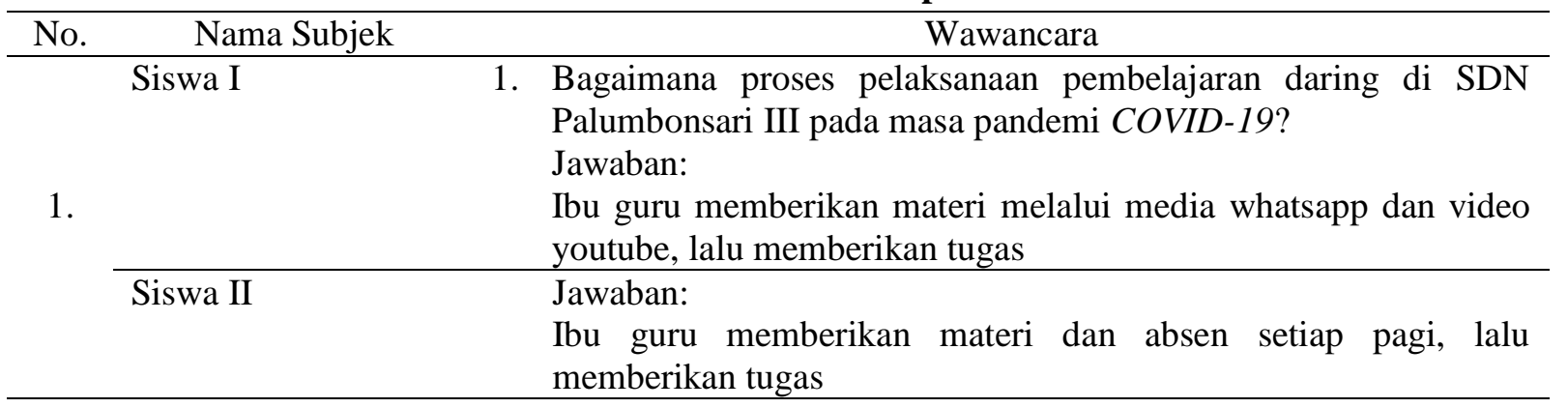

Siswa I 2. Apa yang adik rasakan selama pembelajaran daring? Jawaban:

Lebih senang belajar di sekolah karena bisa ketemu teman-teman

2. Siswa II Jawaban:

Lebih suka belajar tatap muka di sekolah karena bertemu ibu guru dan teman-teman bisa bertanya jika tidak paham

3. Aplikasi apa saja yang adik gunakan pada saat pembelajaran daring? 


\begin{tabular}{|c|c|c|}
\hline \multirow[t]{2}{*}{3.} & & $\begin{array}{l}\text { Jawaban: } \\
\text { whatsapp dan youtube }\end{array}$ \\
\hline & Siswa II & $\begin{array}{l}\text { Jawaban: } \\
\text { Ibu guru menggunakan aplikasi whatsApp dan youtube }\end{array}$ \\
\hline \multirow[t]{2}{*}{4.} & Siswa I & $\begin{array}{l}\text { 4. Apa kesulitan yang adik hadapi dalam proses pembelajaran } \\
\text { daring pada masa pandemi COVID-19? } \\
\text { Jawaban: } \\
\text { Signal kurang bagus, kesulitan memahami materi dan mencari } \\
\text { jawaban karena tidak bisa bertanya kepada ibu guru secara } \\
\text { langsung }\end{array}$ \\
\hline & Siswa II & $\begin{array}{l}\text { Jawaban: } \\
\text { Susah memahami materi pembelajaran }\end{array}$ \\
\hline
\end{tabular}

Setelah dilakukan wawancara, dapat dianalisis bahwa pelaksanaan pembelajaran daring di SDN Palumbonsari III secara umum dinyatakan sulit. Karena adanya kendala yang menghambat proses pembelajaran seperti adanya siswa yang tidak memiliki handphone android, orang tua yang tidak bisa menggunakan handphone android, jaringan internet serta tidak adanya kuota internet. Sama halnya dengan penelitian yang dilakukan oleh (Sadikin \& Hamidah, 2020) bahwa kurang kuatnya signal yang berada di pelosok dan mahalnya harga kuota menjadi kendala dalam pembelajaran daring. Selain itu kurangnya pemahaman guru dalam penggunaan aplikasi pembelajaran serta kendala internet menjadi kendala yang dihadapi oleh guru (Fikri et al., 2021). Sejalan dengan penelitian yang dilakukan oleh (Rigianti, 2020), kendala guru dalam pembelajaran daring yaitu aplikasi pembelajaran, jaringan internet dan gawai, pengelolaan pembelajaran, penilaian, dan pengawasan.

Ketika pelaksanaan pembelajaran daring, guru di SDN Palumbonsari III membuat RPP dan menggunakan media serta metode penugasan. Hal ini dilihat dari hasil observasi yang terlihat guru membuat RPP daring. Guru menggunakan media berupa handphone, buku, serta video. Metode yang guru pilih pada saat pembelajaran daring ialah metode penugasan yang mana siswa mendapatkan tugas dari guru. Media pembelajaran yang digunakannya berupa handphone, buku LKS, dan video. Metode yang digunakan saat masa pembelajaran daring yaitu metode penugasan dimana siswa diberikan tugas oleh guru.

Selain guru yang mengalami kesulitan selama pembelajaran daring berlangsung, siswa pun memiliki kesulitan selama pembelajaran daring. Kesulitan tersebut dari interaksi dan komunikasi antara guru dan siswa yang tidak maksimal sehingga siswa tidak paham akan materi yang diajarkan. Selama masa pandemi COVID19 siswa mengatakan bahwa proses pembelajaran lebih menyenangkan di sekolah dibandingkan di rumah. Pembelajaran tatap muka lebih disenangi siswa karena dapat berkomunikasi secara langsung dengan guru dan bersosialisasi dengan teman-teman. Guru kelas IV pun mengatakan bahwa siswa lebih antusias belajar tatap muka di kelas dibandingkan dengan belajar daring.

Berdasarkan hasil wawancara di atas yang peneliti lakukan diketahui bahwa proses belajar mengajar semasa pandemi COVID-19 disampaikan melalui whatsApp group kelas, materi disampaikan oleh guru dalam bentuk teks, video, dan audio disetiap harinya. Dilihat pada whatsApp group kelas siswa mendapatkan materi pelajaran yang disampaikan melalui video atau voice note yang guru berikan setiap pagi. Di lihat pesan didalam whatsApp group kelas IV guru memberikan materi serta penugasan kepada siswa. Guru meminta siswa mengerjakan LKS. Pengumpulan tugas dilakukan secara online dan offline. Online siswa mengirimkan foto atau video hasil dari penugasan guru sesuai dengan batas waktu yang diberikan. Offline dilakukan sesuai jadwal yang telah dibuat oleh sekolah. Siswa datang ke sekolah untuk mengumpulkan dan mengambil tugas setiap dua kali dalam seminggu. terihat guru datang ke sekolah sesuai jadwal yang telah dibuat dan siswa maupun orang tua datang ke sekolah untuk mengumpulkan dan mengambil kembali tugas dari guru. Seperti 
dikatakan oleh (Ding et al., 2020) bahwa ada banyak tantangan dalam pembelajaran daring dengan menggunakan aplikasi whatsapp.

Jadi berdasarkan hasil wawancara dapat disimpulkan bahwa pemanfaatan teknologi informasi dalam pembelajaran daring di sekolah dasar, mayoritas siswa dan guru menggunakan whatsapp dan aplikasi youtube. Dengan adanya teknologi informasi yang semakin canggih, guru diharapkan untuk lebih kreatif dan melek teknologi. Guru tidak hanya memanfaatkan teknologi informasi whatsApp dan youTube saja tetapi guru bisa memanfaatkan media pembelajaran berbasis multimedia interaktif yang di buat oleh guru secara sistematis dan menarik untuk menyampaikan informasi atau materi pembelajaran agar pelaksanaan pemebelajaran daring pada masa pandemi COVID-19 ini lebih efektif dan tidak membosankan untuk siswa. Maka dari itu dalam hal meningkatkan kemampuan penguasaan teknologi bagi guru dapat dilakukan beberapa diantaranya dengan mengikuti kegiatan pelatihan atau seminar mengenai TIK, melengkapi sarana dan parasarana berbasis TIK guna menunjang pembelajaran selain itu dengan mengadakan studi banding ke sekolah yang dipandang lebih maju dalam bidang TIKnya (Dewi \& Hilman, 2019).

\section{KESIMPULAN}

Berdasarkan hasil penelitian yang telah dilaksanakan di SDN Palumbonsari III mengenai pemanfaatan teknologi informasi dalam pembelajaran daring ada masa pandemi COVID-19 dengan metode kualitatif deskriptif melalui teknik pengumpulan data berupa observasi, wawancara dan dokumentasi dapat disimpulkan bahwa proses pelaksanaan pembelajaran daring di SDN Palumbonsari III sudah terlaksana dengan cukup baik memanfaatkan teknologi informasi tetapi masih dinyatakan belum maksimal karena adanya beberapa kendala. Kendala yang menghambat proses pembelajaran seperti adanya siswa yang tidak memiliki handphone android, orang tua yang tidak bisa menggunakan handphone android, jaringan internet serta tidak adanya kuota internet. Proses pembelajaran daring seluruhnya dengan memanfaatkan teknologi informasi yang dilaksanakan melalui aplikasi whatsapp. WhatsApp digunakan untuk berkomunikasi dengan siswa dan orang tua mengenai pelaksanaan pembelajuaran daring. Selain untuk berkomunikasi whatsapp juga digunakan untuk mengirimkan informasi mengenai pembelajaran daring. Sedangkan youtube digunakan untuk proses penyampaian materi pembelajaran.

\section{DAFTAR PUSTAKA}

Adisel, Gawdy, A. P. (2020). Penggunaan Teknologi Informasi Dan Komunikasi Dalam Sistem Manajemen Pembelajaran Pada Masa Pandemi Covid 19. Alignment: Journal Of Administration And Educational Management.

Afrianti, W. E. (2018). Penerapan Google Classroom Dalam Pembelajaran Akuntansi (Studi Pada Program Studi Akuntansi Universitas Islam Indonesia). In Skripsi.

Amran, Suhendra, Wulansari, R., \& Farrahatni, F. (2021). Hambatan Siswa Dalam Pembelajaran Daring Pada Mata Pelajaran Matematika Pada Masa Pandemik COVID-19 Di Sekolah Dasar. Jurnal Basicedu, 5(6), 5179-5187.

Astini, Sari, N. K. (2020). Pemanfaatan Teknologi Informasi Dalam Pembelajaran Tingkat Sekolah Dasar Pada Masa Pandemi COVID-19. Jurnal Lembaga Penjaminan Mutu Stkip Agama Hindu Amlapura, $11(2), 13-25$.

Darimi, I. (2017). Teknologi Informasi Dan Komunikasi Sebagai Media Pembelajaran Pendidikan Agama Islam Efektif. In Jurnal Pendidikan Teknologi Informasi.

Dewi, S. Z., \& Hilman, I. (2019). Penggunaan Tik Sebagai Sumber Dan Media Pembelajaran Inovatif Di Sekolah Dasar. Indonesian Journal Of Primary Education, 2(2), 48. 

COVID-19 di Sekolah Dasar - Yulistina Nur DS , Harmawati, Restaringga Maulana DOI: https://doi.org/10.31004/basicedu.v6i1.2022

Https://Doi.Org/10.17509/Ijpe.V2i2.15100

Ding, J., Hermawati, D., \&, \& Subakti, H. (2020). Analisis Media Pembelajaran Daring Di Era Pandemi COVID-19 Pada Kelas Iii Sd Negeri 027 Samarinda Ulu. Sistema: Jurnal Pendidikan, 01(02), 16-23. Https://Jurnal.Fkip-Uwgm.Ac.Id/Index.Php/Sjp/Article/View/639

Fikri, M., Ananda, M. Z., Faizah, N., Rahmani, R., Elian, S. A., \& Suryanda, A. (2021). Kendala Dalam Pembelajaran Jarak Jauh Di Masa Pandemi COVID-19: Sebuah Kajian Kritis. Jurnal Education And Development Institut Pendidikan Tapanuli Selatan, 9(1), 145-148. Http://Journal.Ipts.Ac.Id/Index.Php/Ed/Article/View/2290

Habibah, R., Salsabila, U. H., Lestari, W. M., Andaresta, O., \& Yulianingsih, D. (2020). Pemanfaatan Teknologi Media Pembelajaran Di Masa Pandemi COVID-19. Trapsila: Jurnal Pendidikan Dasar, 2(02), 1. Https://Doi.Org/10.30742/Tpd.V2i2.1070

Hanifah Salsabila, U., Irna Sari, L., Haibati Lathif, K., Puji Lestari, A., \& Ayuning, A. (2020). Peran Teknologi Dalam Pembelajaran Di Masa Pandemi COVID-19. Al-Mutharahah: Jurnal Penelitian Dan Kajian Sosial Keagamaan. Https://Doi.Org/10.46781/Al-Mutharahah.V17i2.138

Huda, I. A. (2020). Perkembangan Teknologi Informasi Dan Komunikasi (Tik) Terhadap Kualitas Pembelajaran Di Sekolah Dasar. Jurnal Pendidikan Dan Konseling (Jpdk), 2(1), 121-125. Https://Doi.Org/10.31004/Jpdk.V1i2.622

Kuntarto, E., Sofwan, M., \& Mulyani, N. (2021). Analisis Manfaat Penggunaan Aplikasi Zoom Dalam Pembelajaran Daring Bagi Guru Dan Siswa Di Sekolah Dasar. Jurnal Pendidikan Dasar Nusantara, 7(1), 49-62. Https://Doi.Org/10.29407/Jpdn.V7i1.15742

Nadziroh, F. (2017). Analisa Efektifitas Sistem Pembelajaran Berbasis E-Learning. Jurnal Ilmu Komputer Dan Desain Komunikasi Visual (Jikdiskomvis).

Naserly, M. K. (2020). Implementasi Zoom, Google Classroom, Dan Whatsapp Group Dalam Mendukung Pembelajaran Daring (Online) Pada Mata Kuliah Bahasa Inggris Lanjut. Journal Of Chemical Information And Modeling.

Natsir, S. R., Sari, E. R., Lestari, A. A., Guru, P., Dasar, S., \& Buton, U. M. (2021). Elementary Education Https://Jbasic.Org/Index.Php/Basicedu. 5(6), 5014-5023.

Pakpahan, R., \& Fitriani, Y. (2020). Analisa Pemafaatan Teknologi Informasi Dalam Pemeblajaran Jarak Jauh Di Tengah Pandemi Virus Corona COVID-19. Jisamar (Journal Of Information System, Applied, Management, Accounting And Researh).

Pendidikan, S. (2020). Implementasi Model Pembelajaran Daring Pada Masa Pandemi COVID-19 Di Kelas Iii Sd Ptq Annida Kota Salatiga Tahun Pelajaran 2020 Skripsi.

Putria, H., Maula, L. H., \& Uswatun, D. A. (2020). Analisis Proses Pembelajaran Dalam Jaringan (Daring) Masa Pandemi Covid- 19 Pada Guru Sekolah Dasar. Jurnal Basicedu. Https://Doi.Org/10.31004/Basicedu.V4i4.460

Rigianti, H. A. (2020). Kendala Pembelajaran Daring Guru Sekolah Dasar Di Banjarnegara. Elementary School: Jurnal Pendidikan Dan Pembelajaran Ke-Sd-An. Https://Doi.Org/10.31316/Esjurnal.V7i2.768

Sadikin, A., \& Hamidah, A. (2020). Pembelajaran Daring Di Tengah Wabah COVID-19:(Online Learning In The Middle Of The COVID-19 Pandemic). Biodik: Jurnal Ilmiah Pendidikan Biologi.

Sugiyono. (2017). Metodepenelitian Kuantitatif, Kualitatif Dan R\&D. Bandung: Pt Alfabet. In Sugiyono. (2017). Metodepenelitian Kuantitatif, Kualitatif Dan R\&D. Bandung: Pt Alfabet. 